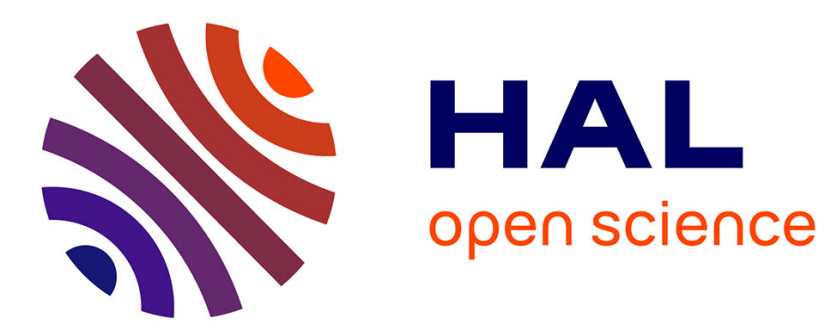

\title{
Does one size fit all? The impact of cognitive skills on economic growth
}

Nadir Altinok, Abdurrahman Aydemir

\section{To cite this version:}

Nadir Altinok, Abdurrahman Aydemir. Does one size fit all? The impact of cognitive skills on economic growth. 2016. halshs-01376281

\section{HAL Id: halshs-01376281 https://shs.hal.science/halshs-01376281}

Preprint submitted on 4 Oct 2016

HAL is a multi-disciplinary open access archive for the deposit and dissemination of scientific research documents, whether they are published or not. The documents may come from teaching and research institutions in France or abroad, or from public or private research centers.
L'archive ouverte pluridisciplinaire HAL, est destinée au dépôt et à la diffusion de documents scientifiques de niveau recherche, publiés ou non, émanant des établissements d'enseignement et de recherche français ou étrangers, des laboratoires publics ou privés. 


\section{Les Documents de Travail de l'IREDU}

Working Papers

\section{Institut de Recherche sur l'Education}

Sociologie et Economie de l'Education

Institute for Research in the Sociology and Economics of Education

Does one size fit all?

The impact of cognitive skills on economic growth

Nadir Altinok and Abdurrahman Aydemir

Septembre 2016

DT 2016/1

Pôle AAFE - Esplanade Erasme - B.P. 26513 - F 21065 Dijon Cedex

Tél.+33 (0)3 80395450 - Fax +33 (0)3 80395479

iredu@u-bourgogne.fr- http://iredu.u-bourgogne.fr 
Les Documents de travail de l'IREDU n'engagent que leurs auteurs. L'objet de leur diffusion est de stimuler le débat et d'appeler commentaires et critiques. Ils peuvent ensuite donner lieu à des publications dans des revues scientifiques.

Working Papers do not reflect the position of IREDU but only their author's views. 


\title{
Does one size fit all? The impact of cognitive skills on economic growth
}

\author{
Nadir Altinok and Abdurrahman Aydemir ${ }^{1}{ }^{2}$
}

This version: 30/09/2016

\begin{abstract}
This paper tests for heterogeneous effects of cognitive skills on economic growth across countries. Using a new extended dataset on cognitive skills and controlling for potential endogeneity, we find that the magnitude of the effect is about $60 \%$ higher for low-income countries compared to high-income countries, and it more than doubles when low TFP countries are compared to high TFP countries. There are also marked differences across geographic regions. Using data on the share of the population with advanced and minimum skill levels, our results also indicate that high-income countries should focus on increasing the number of high skilled human capital, while countries from Sub-Saharan Africa would benefit more by investing in the development of basic skills.
\end{abstract}

Keywords : Education, Development, Africa, Cognitive Skills, Growth, Heterogeneity.

J.E.L. Classification: H5, I25, N37, O1.

\footnotetext{
${ }^{1}$ Nadir Altinok: IREDU, BETA, UMR CNRS 7522\& University de Lorraine (France), Faculté de Droit, Sciences économiques et Gestion, 13, placeCarnot, CO26, 54035 Nancy Cedex, France. nadir.altinok@univ-lorraine.fr Abdurrahman Aydemir : Sabancı University, Faculty of Arts and Social Sciences, Orhanl, Tuzla 34956, Istanbul, IZA, CReAM-UCL,aaydemir@sabanciuniv.edu

${ }^{2}$ We are grateful to Theodore Breton, Erik Hanushek, Geraint Johnes, Jean-Luc de Meulemeester and Lant Pritchett for their valuable comments. We also benefited from the comments of the participants of the 19th EBES Conference and the International Symposium on Education and Training organized by the CSEFRS. This work has been partly supported by the AFD (Agence Française de Développement). Usual disclaimers apply.
} 


\section{Introduction}

The question of which factors determine economic growth has been a major topic in economic research. Many previous studies have analyzed the impact of education on economic growth (see Glewwe et al., 2014, Durlauf, Johnson, and Temple,2005for literature reviews). ${ }^{3}$ The importance of human capital for economic growth has been called into question by a large number of studies that failed to find a positive relationship between the quantity of education and economic growth in cross-country analysis. In 2001, Lant Pritchett underlined the controversies surrounding the relationship between education and growth (Pritchett, 2001). Pritchett highlighted the importance of the quality of education and argued that if the quality of education is so low it may not produce the necessary skills to lead to economic growth.

Recent studies have pointed out the importance of school quality as opposed to quantity (Barro, 1991, Hanushek and Kimko, 2000, Hanushek and Woessmann, 2012a) and have provided evidence of the positive effect of school quality on the rate of economic growth. Barro (1991) was the first study to emphasize school quality along with other measures of education. Barro presented evidence that school quality matters; higher primary and secondary pupil-teacher ratios in 1960 have marginally significant negative impacts. ${ }^{4}$ Following Barro's analysis that underlined the importance of school quality, the work of Hanushek and Kimko (2000) was the first to include measures of educational quality using data from international student achievement tests

\footnotetext{
${ }^{3}$ The question raised by Levine and Renelt (1992) was revisited by Sala-I-Martin, Doppelhofer, and Miller (2004) who ranked variables by their robustness in growth regressions and found that the 1960 primary school enrolment rate is the second most robust variable. Durlauf et al. (2005) on the other hand highlight in their review that perhaps the high standard set by Levine and Renelt (1992) may be too strict.

${ }^{4}$ Including a school quality variable can also be interpreted as correcting for measurement error, since years of schooling or enrolment rates may measure human capital with error.
} 
(hereafter ISATs) ${ }^{5}$. A recent paper by Hanushek and Woessmann (2012a) (hereafter HW) aimed at improving the work of Hanushek and Kimko (2000). Using the Cohen and Soto (2007) years of education dataset, they update test score data that include more developing countries (50 countries, of which 27 are developing countries) and the period analyzed is extended to cover the 1960-2000 period. Their database includes a combined measure for the 50 countries that have ever participated in any of the math and science tests. Confirming results from Hanushek and Kimko (2000), HW find that years of schooling have no impact on economic growth when the test score measure is included. A onestandard deviation increase in school quality, on the other hand, is associated with a 1.3-2.0 percentage point higher rate of economic growth. However, HW do not test for heterogeneity issues, because of data limitations.

Our paper aims at improving and extending the literature in a number of ways. Firstly, in addition to estimating an average effect of education on economic growth, we also test for heterogeneity in these effects. This paper is the first comprehensive study in the literature that assesses within a causal framework the differences in the amplitude of cognitive skills and growth relationship. ${ }^{6}$ In particular, we exploit the availability of more than 80 countries in our data and provide estimates separately by income level of countries and total factor productivity. Our analysis also provides novel evidence on the cognitive skills and economic growth relationship by geographic region. For example, among other regions, our analysis provides

\footnotetext{
${ }^{5}$ An important number of research papers analyzed the education-growth relationship. In this paper, we only focus on studies that have included a qualitative dimension to education.For further details, see the comprehensive review by Durlauf, Johnson, and Temple (2005).

${ }^{6}$ Castelló-Climent and Hidalgo-Cabrillana (2012) develop a theoretical model of human capital investments distinguishing between low- and high-quality education. Using the Hanushek and Kimko (2000) dataset, they show the education quality has a positive effect on growth only when quality is relatively high. Their main empirical exercise, however, does not control for potential endogeneity of cognitive skills and includes few developing countries.
} 
results for Arab countries and Sub-Saharan African countries, a region the growth experience of which received little attention by previous studies due to data constraints.

There are important differences across countries in terms of economic activity and distance to the technological frontier. While in some contexts -such as countries that create technologies- the role of elites may be more important, in others -such as countries that are mainly imitators- basic skills may play a more significant role. Thus, we also conduct an analysis that tests whether the effect of minimum and advanced level of cognitive skills varies between countries. This analysis aims at answering which types of skills matter most for the economic growth of less developed and more developed regions.

On the methodological front, while most previous analyses fail to take into account potential endogeneity issues, we control for potential endogeneity and measurement error by using an IVGMM estimation strategy. In addition to instruments used in earlier pioneering work, several new instruments have been proposed recently in the literature studying education and growth relationship (Islam et al., 2014; Adams-Kane \& Lim, 2014). We present results from these alternative estimation methods for identifying the causal effect of education quality on growth. Thus, the paper also tests the robustness of the estimated impact of cognitive skills on economic growth to different estimation strategies and subsamples.

The analysis in this paper is made possible using an alternative, more recent and extended dataset. Our dataset substantially extends the coverage of countries, particularly less developed ones, that could not be included in growth regressions by previous studies. For example, among the newly added countries, our database includes 27 countries of Sub-Saharan Africa, a continent that was largely missing from the analysis of the effects of learning outcomes on economic 
growth. The study also updates the period of analysis by including the most recent data on schooling quality (between 1965 and 2012).

Our analysis yields four main results. i) While we cannot find a robust effect of the quantity of schooling (measured as initial years of education), the coefficient associated with our updated cognitive skills variable is quite strong over most estimations. These results confirm those reported by HW. ii) Our results show that including more developing countries increases the overall impact of cognitive skills on economic growth by about 27\%. iii) Moreover, we find that the magnitude of the effect is about $60 \%$ higher for low-income countries compared to highincome countries, more than doubles when low TFP countries are compared to high TFP countries. There are also marked differences across geographic regions. iv) Lastly, a focus on the share of basic and top performers within each country highlights different effects between subsamples. While in high-income countries the share of top performers in student achievement tests has a strong and positive effect on economic growth, it is the share of students reaching the minimum level which has the most impact on economic growth for countries from Arab States and Sub-Saharan Africa.

In section 2, we outline a simple growth model that forms the basis of our estimation. Section 3 presents the data sources and general methodology used to construct our database on the test scores measure. Section 4 estimates the contribution of the quality of education to economic growth in a cross-section dataset, and deals with potential endogeneity and measurement error bias. In section 5,we explore potential heterogeneity of the impact of cognitive skills in economic growth. For this purpose we provide estimates for different subgroups and also consider alternative measures of cognitive skills (i.e. minimum and advanced levels of cognitive skills).Section 6 concludes. 


\section{A Simple Growth Model}

Following HW, we use a simple growth model: a country's growth rate $(g)$ is a function of the skills of workers $(H)$ and other factors $(X)$. These factors include initial levels of income and technology, specific institutional dimensions, and other factors that are used in the growth empirics. Skills are often referred to simply as the workers' human capital stock. Our specification assumes that $H$ is a one-dimensional index and that growth rates are linear in these inputs:

$$
g=\gamma H+\beta X+\varepsilon
$$

The most important specification issue in this framework is the nature of the skills $(\mathrm{H})$ and where they might come from. In the educational production function literature (Hanushek, 2002) skills are explained by many factors such as family inputs $(F)$, the quantity and quality of inputs provided by schools $(q S)$, individual ability $(A)$, and other relevant factors $(Z)$ which include labor market experience, health, and other specific characteristics:

$$
H=\alpha F+\beta(q S)+\gamma A+\delta Z+v
$$

Human capital, however, is a latent variable that cannot be directly observed. Hence, we need a correct measure of human capital in order to test its impact on economic growth. The main existing theoretical and empirical work on growth begins by taking the quantity of schooling of workers $(S)$ as a direct measure of $H$. Following the pioneering analysis of Hanushek and Kimko (2000), we focus on the cognitive skills component of human capital and evaluate $H$ with testscore measures of mathematics, science, and reading achievement. There are many advantages of using measures of educational achievement (Hanushek and Woessmann, 2012). Firstly, they 
capture outputs of schooling by focusing on differences in the knowledge and ability generated by schools. Secondly, since they include all the general skills, they do not only rely on school skills but also skills from other sources (families and general ability). Another important advantage of using cognitive skills is the ability to assess the importance of different policies designed to affect the quality aspects of schools since cognitive skills allow for differences in performance among students with the same quantity of schooling.

\section{Data and methodology}

The dataset related to cognitive skills used in this paper builds upon the work of Altinok et al. (2014) and updates the 1960-2007 data to 1960-2012. Based on new data sources and the alternative method of anchoring, there are several innovations in this dataset compared to previous research. The construction of this data benefits from international student achievement tests (ISATs) as well as regional student achievement tests (RSATs). ISATs include the wellknown TIMSS, PIRLS and PISA tests. ${ }^{7}$ Along with these international assessments, three major RSATs are conducted in Africa and Latin America, such as LLECE, SACMEQ or PASEC ${ }^{8}$, which were not used in previous research on the effect of cognitive skills on economic growth. ${ }^{9}$ These tests help us to extend the available data to a larger set of countries, improving the representation of developing world with substantial improvements for Africa and Latin America. For instance, our updated dataset includes 27 countries of sub-Saharan Africa. ${ }^{10}$ The resulting

\footnotetext{
${ }^{7}$ Respectivelythe Trends in International Mathematics and Science Study (TIMSS), Progress in International Reading Literacy Study (PIRLS) and Programme for International Student Assessment (PISA).

${ }^{8}$ Respectively the Latin American Laboratory for Assessment of the Quality of Education (LLECE), the Southern and Eastern Africa Consortium for Monitoring Educational Quality (SACMEQ) and the Program on the Analysis of Education Systems (PASEC).

${ }^{9}$ A description of various existing learning assessments is provided in Appendix A and detailed information on each assessment is provided in Table A.1.

${ }^{10}$ Table A.3 provides the list of countries in our data with information on all three measures of skills: average test scores, shares of students reaching basic literacy and advanced level in achievement tests. The table also lists the countries used in earlier work by HW. Compared to earlier work the number of countries included in growth
} 
updated database in this paper includes comparable cognitive skills for 125 countries, as compared to HW who take into account 77 countries between 1960 and $2000 .{ }^{11}$ While the dataset of HW includes data for about 4.7 billion people, our updated dataset increases this number by about $10 \%$. The coverage is much more substantial for Arab states and Sub-Saharan Africa: while the HW study covers around 220 million people from this region, our updated dataset comprise more than double this figure (approximately 500 million people).

The methodology to generate comparable achievement scores across countries used in Altinok et al. (2014) aims at improving the seminal work by Barro and Lee (1996) and Barro (2001), and consists of a major update of a previous work by Altinok and Murseli (2007). Hanushek and Kimko (2000) and Hanushek and Woessmann (2012a) also use a method of anchoring for their database of cognitive skills across 77 countries. The alternative methodology for creating the data used in this paper differs from Hanushek and Woessmann (2012a) in that it takes into account several improvements made by ISATs since 1995 and enables the inclusion ofthe main regional assessments that were absent in previous datasets. Details of this methodology are provided in Appendix A.

Ideally, the evaluation of the impact of cognitive skills on economic growth would need measures of the skills of workers in the labor force. However, some of our measures of cognitive skills based on recent testing (e.g. the tests conducted after late 2000s)include students who are still in school. As has been highlighted by HW, this creates a tradeoff: incorporating more recent

regressions increases from 6 to 23 for African countries while the number of Latin American countries increases from 7 to 16 .

${ }^{11}$ It should be noted that the number of countries included in estimations is always lower than the number of countries for which we have comparable data on cognitive skills. The main reason is the lack of data on other explanatory variables. For instance, while HW compiled comparable data on cognitive skills for 77 countries, only 50 of them were included in different estimations. In our case, while we have data on cognitive skills for 125 countries, our estimation sample is reduced to around 80 countries due to missing data on other explanatory variables. 
testing has the potential advantages of improved assessments and observations on a greater number of countries (especially developing countries) but it also weights any country measure more toward students and less toward workers. ${ }^{12}$

\section{Baseline results}

In this section, we report cross-sectional estimates of the cognitive skills and economic growth relationship based on equation (1). Since we use a new extended dataset based on a different methodology to HW, before reporting results from our extended data we first replicate results from HW using their own data as well as our dataset confined to the HW sample. Table 1 presents the baseline results. This table is divided into three panels. The first panel (Panel A) replicates Table 1 from HW using the same dataset and sample of countries. In Panel B of Table 1, we use our dataset that extends the years used for calculation of test scores to 2012 but restrict the sample to the countries in HW. This allows us to check to what extent the longer time span for the tests in our dataset provides additional information compared to previous research. Panel C of Table 1 uses our dataset with the extended set of countries and aims to test the robustness of previous estimates to the inclusion of additional countries. ${ }^{13}$

Results from Panel A replicate the estimation of HW for the 50 countries with cognitive skills and economic data over the period 1960-2000. Following their methodology, we use version 6.1 of the Penn World Tables (Heston et al., 2002), while the data on years of schooling come from

\footnotetext{
12 Two international tests (the International Assessment of Adult Literacy and the Programme for International Assessment of Adult Competencies) offer the possibility of panel estimation across countries as they have tested adults rather than students (see Coulombe \& Tremblay, 2006; Hanushek \& Woessmann, 2015).

${ }^{13}$ Because we need data for economic growth and cognitive skills between 1960 and 2010, all former communist countries are eliminated even if they have test measures. This explains why our estimation does not include 125 countries.
} 
Cohen and Soto (2007). ${ }^{14}$ The first column of Panel A presents estimates of a simple growth model with school attainment. In the second column, adding cognitive skills increases the explained variance from $31 \%$ to $75 \%$. Whether we include (col. 3) or exclude (col. 2) initial school attainment in 1960 yields similar results where the coefficient estimates for the "cognitive skills" variable are significant with an amplitude quite similar to those reported by HW. The remaining columns of Panel A provide results from alternative specifications. ${ }^{15}$ Although the amplitude of the effect of cognitive skills is reduced, it remains significant in all specifications, confirming the results of HW. Also, in all estimates where the cognitive skills variable is included, the initial years of schooling have no significant impact on economic growth.

In Panel B, we use the scores for cognitive skills based on the new data source (i.e. the updated version of Altinok et al., 2014) but still restrict the sample of countries to that of HW. Across columns (2) to (9) of Panel B, coefficient estimates for our "cognitive skills" remain significant. The precision of coefficient estimates, as reflected by the t-statistics, are similar to those in Panel A implying that our data are at least as predictive as the data used by HW for the restricted set of countries. The overall effect of cognitive skills on economic growth is however slightly higher in our dataset. ${ }^{16}$

In Panel C, we still use our alternative measure of cognitive skills, but now extend our sample from 50 to 84 countries. Most of the newly included countries are from Sub-Saharan Africa and

\footnotetext{
${ }^{14} \mathrm{HW}$ explain that they use an extended version of the Cohen and Soto (2007) data. However, they do not explicitly explain the methodology used. We predict results from the Barro and Lee (2013) dataset for missing values from Cohen and Soto (2007) data. This may explain slight differences in results.

${ }^{15}$ In column 5, we employ regression techniques that are robust to outliers (excluding Botswana and Nigeria) while in column 6 we include regional dummies. In columns 7 and 8, we consider economic institutions. We control for institutional differences in openness of the economy and security of property rights in column 7 and introduce fertility rates and location in the tropics as additional controls in column 8.

${ }^{16}$ This may be explained by the fact that we do not include in our dataset results from IAEP and results that refer to the end of secondary schools. The bias included in the IAEP survey has been well documented in the literature (see for instance Rotberg, 1990; McLean, 1990; Goldstein, 1993). Moreover, since the survival rates to the last grade of secondary education greatly differ between countries, we prefer not to include results from TIMSS-Advanced in our dataset.
} 
Latin America (see Table A.3 for a full list of countries included in our regressions). ${ }^{17}$ The results confirm a strong positive relationship between cognitive skills and economic growth that remains significant across different specifications. Comparing results in column 3 across the three panels shows that the estimated effect in Panel C (1.5 percent) is about 25\% higher than that in Panel A (1.2 percent). This comparison also shows that the rise in estimated effect is mainly due to expansion of the sample in Panel C, from 50 to 84 countries, that includes more developing countries.

In order to test for robustness, in Appendix Table A.4 $4^{18}$, we present the estimated cognitiveskill coefficients for different samples of countries and time periods, such as distinguishing between OECD and non-OECD countries or restricting the growth regressions to 1960-80 and 1980-2010 periods. Results from Table A.4 are quite similar to estimates from HW with only slight differences in some cases. ${ }^{19}$ In the Appendix Table A.5, we perform a further robustness analysis that considers alternative aggregation of test scores. ${ }^{20}$ Our results continue to show a strong relationship between skills and growth across panel seven when the number of countries with available data is reduced from 80 to 46.

\footnotetext{
${ }^{17}$ In our dataset, similarly to HW, we exclude five countries which can be considered as outliers (Botswana, Gabon, Kenya, Luxembourg and Mauritania).Luxembourg is known as a country which has economic growth mainly based on tax-free policies, so the relationship between cognitive skills and economic growth can be flawed. The remaining African countries are excluded since either we only have one observation (Mauritania) or test results are contradictory between assessments (Botswana, Kenya, Gabon).

${ }^{18}$ Appendix of the paper can be downloaded at the following link: https://goo.gl/J5hpBX

${ }^{19}$ This may be either due to differences in methodology used in some estimations or the fact that upper secondary schools are excluded from our analysis.

${ }^{20}$ Under the assumption of stable test performance over time, row A uses test scores since 1995 that are thought be a product of a higher standard of sampling and quality control; row B restricts the tests in this time span to tests using only lower secondary scores. A drawback of using only the most recent tests is that this assumes the test performance to be quite stable over time, since we relate test performance measured since 1995 to the economic level data for 1960-2010. In order to test that higher past economic growth is not impacting our measured test performance, we restrict the test-score measure used in row $\mathrm{C}$ to all tests until 1995. Rows D to F use test scores individually, while row $\mathrm{G}$ uses test scores jointly.
} 
Above results show a strong positive relationship between cognitive skills and economic growth using cross-sectional variation. While the results are robust across various specifications and subsamples, reverse causality and endogeneity bias may potentially be driving the results. Reverse causality would arise if higher economic growth enables countries to develop better education systems that yield higher test performance. The presence of other factors, such as institutions or access to natural resources, which affect growth and are also correlated with cognitive skills will lead to an endogeneity bias in our estimations. Below, we address the potential endogeneity of cognitive skills within an instrumental variable framework using various instruments.

Hanushek and Woessmann (2011) show that measures of the institutional structure of the school systems are associated with international educational production, hence, HW propose to use these measures as instruments for cognitive skill. The instruments used by HW include share of students subject to external exit exam system, catholic share in 1900, and relative teacher salary. ${ }^{21}$ Using these instruments we present results in the appendix Table A.6. Columns 1, 3, and 5 of Table A.6 report results that use data from HW while columns 2, 4 and 6 use our updated data. ${ }^{22}$ The relevance of the instruments is tested in the first-stage regressions and results are reported in the table. ${ }^{23}$ The first-stage $\mathrm{F}$ value is low in some cases, which may lead to a weak instrument problem. Hence, we also report results based on the modification of the limited

\footnotetext{
${ }^{21}$ We also estimated models with other instruments reported by HW. However, data was lacking for a large number of countries, so we do not report these results in the paper. These results are available on request.

${ }^{22}$ Columns 1 and 2 use the share of students in a country who are subject to external exit exams as an instrument for the measure of cognitive skills in the growth regression. Columns 3 and 4 use teacher salaries relative to per-capita income as an instrument while columns 5 and 6 use the share of Catholics in a country's population in 1900 as an instrument. Initial years of schooling variable is not significant in previous estimations once tests scores are controlled for, hence, satisfies exclusion restriction. Therefore, similar to previous work by HW, in all three specifications we also include initial years of schooling as an instrument for test scores to improve instrument relevance.

${ }^{23}$ As a rule of thumb, the F-Statistic of a joint test whether all excluded instruments are significant should be larger than 10 in case of a single endogenous regressor (Stock, Wright and Yogo, 2002).
} 
information maximum likelihood (LIML) estimator by Fuller (1977) which yields estimates that are very similar to the 2SLS estimates. The use of these instruments - and especially catholic share in 1900 and relative teacher salary - confirm the positive effect of cognitive skills on economic growth. Since this first set of instruments are available only for a limited number of developing countries we conduct further analyses with other alternative instruments.

Several papers use an alternative set of instruments (Islam et al., 2014; Adams and Lim,2014) that allow IV estimation involving a larger set of countries. In addition to using an alternative set of instruments, we also use GMM estimation instead of standard 2SLS. A key advantage of the IV-GMM estimator over the IV-2SLS approach is that the former is more efficient in the presence of heteroscedasticity. IV-GMM is also our preferred method because under the strict assumption of no heteroscedasticity, the IV-GMM is asymptotically no worse than the IV-2SLS estimator (Baum, Schaffer, and Stillman, 2003).

The first set of alternative instruments are (1) disability-adjusted life years lost per 100,000 population (DALY) due to communicable, maternal, perinatal, and nutritional diseases (excluding DALY due to noncommunicable diseases such as cancer, cardiovascular diseases, and injuries which are unlikely to influence school performance) and (2) estimated death rates due to communicable, maternal, perinatal, and nutritional diseases per 100,000 population (EDR). Islam et al. (2014) argue that because infectious and parasitic diseases impair the ability to learn, reduce students' attention and concentration in the classroom, and increase student and teaching absenteeism, DALY serves as a good instrument for the quality of learning. DALY is also not likely to be influenced by growth because they are mainly driven by pathogen stress, which is determined by ecology (Guernier et al., 2004). For the same reasons underlying DALY, EDR serves as the second instrument. While these two instruments have a large overlap, Islam et 
al.(2014) explain the advantages of each one over the other and uses them separately in their analysis.

Estimation results using these new instruments are presented in Table 2. While in previous IV estimations only 50 countries were included, with the use of these instruments our sample now includes 78 countries, an increase of $60 \%$ in the number of countries. We first include DALY as the only instrument (column 1). Results from the first stage indicate an expected (negative) and significant relation with cognitive skills. The F-statistic at 47 is higher than the threshold of 10 and much higher than the F-statistics reported in Table A.6. Columns 2 to 5 use as instruments either only EDR, or only DALY, or both, and introduce initial years of schooling as an additional instrument. Columns 6 and 7 distinguish between OECD and non-OECD countries. All of the resulting estimates in columns 1 though 7 suggest a positive impact of cognitive skills on growth where the magnitude of estimated coefficients is remarkably robust across specifications and also quite close to the estimate reported by column 6 of Table A.6, which uses the extended set of countries. Comparison of columns 6 and 7 indicate that the effect is larger for non-OECD countries (column 7) compared to OECD countries (column 6). The Fuller modification has been made for all estimates and does result in quite similar coefficient estimates, showing that the included instruments are quite useful in the cognitive skills-economic growth relationship ${ }^{24}$. The Sargan statistic also does not reject the overidentification test.

Adams and Lim (2014) argue that the potential effect of governance effectiveness on the per capita income of countries is likely to be driven mainly through its mediating effect on the delivery of education. Given the facts that policies that can be more directly associated with

\footnotetext{
${ }^{24}$ Fuller's modification of the LIML estimator is more robust than 2SLS in the presence of weak instruments. Moreover, this modification provides better performance in the simulations by Hahn et al. (2004). We set the userspecified constant (Fuller 1977's alpha) to a value of one, but our results are hardly affected if we set alpha to four.
} 
governance effectiveness tend to be insignificant in standard cross-country growth regressions and the absence of a robust relationship between public education expenditures and growth (Levine and Renelt, 1992; Sala-i-Martin et al., 2004), the quality of public financial management is unlikely to have a direct effect on economic growth. As a result, the measure of governance effectiveness can be considered as a valid instrument for our cognitive skills measure. We use the "Worldwide Governance Indicators" as our governance effectiveness measure, which captures perceptions regarding the quality of public services and the quality of the civil service (Kaufmann, Kraay \& Mastruzzi, 2011) and serves as a proxy for the quality of educational service delivery. Using the years in which this measure is available (1998, 2000, and annually from 2002 to 2006) we compute a mean score of governance effectiveness for the 1988-2006 period. Column 8 uses governance effectiveness and DALY as instruments and find that both variables are correlated with cognitive skills in the first stage. The coefficient estimate associated with our cognitive skills variable in the second stage remains quite stable, compared to the estimation where DALY was included as an instrument (see col. 1). However, the Sargan statistic rejects the overidentification test, suggesting that our instruments are no longer valid. Therefore, we only include years of schooling and governance effectiveness as instruments (column 9). These two instruments satisfy Sargan test and we obtain a coefficient estimate for cognitive skills that is positive and significant which is quite similar in magnitude to other estimates in Table 2.

A global comparison between different estimates from Tables 1 \&2 shows that IV estimate is higher than OLS estimate. In particular, while a move of one standard deviation of individual student performance translates into 1.5 percentage point difference in annual growth rates in OLS estimates (Table 1, column 3); this effect turns out to be higher by about $25 \%$ with IV estimates (Table 2). The downward bias observed in OLS estimates may be stemming from measurement 
issues, especially for low income countries which took part in student assessments tests like PASEC or SACMEQ. In these assessments, the methodology of scaling is less precise than in international student achievement tests like PISA or TIMSS. Another possible explanation relates with bias occurring when we anchor regional student achievement tests with international student achievement tests. Since, the items in each assessment are not exactly similar, it may be possible that the anchoring methodology used in Altinok et al. (2014) underestimates the performance of pupils who participated in these regional assessments (PASEC, SACMEQ, LLECE).

To sum up, the coefficient estimates for cognitive skills indicate a robust impact of cognitive skills on economic growth regardless of the estimation technique used. It is interesting to measure the level of one standard deviation in terms of score points. Since one standard deviation is equal to 100 points in our scale, this represents approximately the difference of performance between Greece (533 points) and South Korea (628 points). In addition, the difference between Turkey and the remaining OECD countries is approximately equal to 0.5 standard deviation. The strength of the relationship between skills and growth may be quite different across such countries with different economic structures.

\section{Heterogeneity in the Impact of Cognitive Skills on Economic Growth}

Countries place a high priority to investments in education and skills as a key driver of economic growth. The gains from these investments, however, depend on the interactions between skills, technology, and physical capital. For example, investments in skills may result in larger productivity gains in countries where skill supply is scarce compared to countries where skill supply is relatively abundant. Although there are many studies that assess the mean effect of cognitive skills on growth across countries, there has been little research in the literature that 
addresses the heterogeneity of this relationship. The robustness tests in our analysis in TablesA.4 and A.6showed that the division of the sample into OECD and non-OECD countries revealed a somewhat higher impact of cognitive skills on economic growth for non-OECD countries.

A second important issue regarding the heterogeneous effects of skills is which types of skills matter most for economic growth. Acemoglu and Zilibotti (2001) shows that a mismatch between supply of skills and the adopted technology leads to low productivity while Hanushek (2013) provides evidence that the impact of high performers on growth differs between OECD and nonOECD countries. Potential differences in the impact of different types of skills on growth has important policy implications since the countries that aim to improve cognitive skills face the choice of targeting improvements across the whole distribution or placing more emphasis on a specific part of the distribution, such as the bottom or the top.

In this section, we aim to extend the existing literature in a number of ways. We first provide further evidence of the heterogeneity of the relationship between cognitive skills and growth, presenting results for various subsamples that hitherto have not been analyzed. Secondly, we conduct an analysis that tests whether the effect of minimum and advanced levels of cognitive skills differ between countries. Our third contribution is related to the estimation methodology. The few papers in the previous literature that consider the heterogeneity of the relationship between cognitive skills and growth do not address endogeneity of cognitive skills. Using a larger sample of countries, we also address the endogeneity issue through a number of alternative instruments. Since different instruments produce different treatment effects (Heckman and Vytlacil, 2007), use of several instruments allows us to test whether our results are driven by the use of specific instruments. For this analysis we use a single data set that involves a consistently defined human capital measure and apply the same estimation method (IV-GMM) which 
provides comparable results across subsamples. This overcomes the challenge of synthesizing results over different studies that use different methodologies and measures of human capital in different country contexts.

\subsection{Distinction of different subsamples}

In this section, we provide estimates of the effects of cognitive skills on economic growth across different subsamples. We divide the sample into several parts and provide estimates separately by (i) income level of countries, (ii) regions, and (iii) total factor productivity. Higher income countries employ a higher level of capital stock and enjoy higher total factor productivity. Hence, the role of skills in growth for these countries may differ from those of low income countries. There are also significant differences across regions in growth experiences of countries, such as countries in Sub-Saharan Africa and the Middle Eastregistering lower growth rates. Geography influences productivity of human capital through its impact on trade opportunities, natural resource endowments, institutions and the public-health environment (Rodrik, 2002). Therefore, for countries that differ in geography the impact of education on growth may also be different. While the influence of several factors have been studied to explain growth differentials across regions, the role skills play in these growth experiences has received little attention. ${ }^{25}$ In our analysis we provide results for several regions including Arab countries and Sub-Saharan African countries, the continent that could not often be studied separately by previous studies due to data constraints.

\footnotetext{
${ }^{25}$ There is a large literature that investigates the reasons behind growth differentials across countries, focusing on factors such as the role of institutions, government policy, climate, factor endowments (e.g. Hall and Jones, 1999; Mellinger et al., 2000).
} 
The results are presented in Table 3 which is divided into two panels. The first panel reports results from OLS regressions (panel A).The second panel (panel B) report results through rows B1 to B6 that use different combinations of instruments. In all of the IV-GMM estimates initial years of schooling is used as an instrument in combination with one or two other instrumental variables. ${ }^{26}$ In particular, we use governance effectiveness and DALY, two instruments that were proposed by the previous literature (Adams and Lim, 2014;Islam et al., 2014) and proved to be highly correlated with our cognitive skills variable in the first stage results of the IV estimation in Table 2. In addition, we use initial school drop-out rate for primary education and the overall level of income inequality (measured with Gini index) as two additional instruments.

Pupils may leave schools because they do not receive a high standard of education. Indeed, Hanushek et al. (2008), for example, show in a developing country context that a student is much less likely to remain in school if attending a low-quality school rather than a high-quality school. Therefore, school drop-out rate for primary school may serve as a good instrument for education quality or cognitive skills. However, since growth rate of the economy could also impact on drop-out rate, we use the initial level of school dropout as an instrument which is more likely to satisfy the exclusion restriction ${ }^{27}$.

A recent study by Inter-American Bank (1999) shows a positive correlation between income inequality and inequality of education while Krueger (2012) and Corak (2013) show that countries with more inequality as measured by Gini coefficients have less intergenerational mobility. Overall level of inequality may thus capture disparities along the income distribution in

\footnotetext{
${ }^{26}$ Previous sections provided evidence for the validity of initial years of schooling as an instrument in the cognitive skills growth relationship. Nevertheless, we have also carried out estimations that does not use initial years of education as an instrument and obtained results that are very similar to those presented in Table 2. Due to space considerations these results are not presented.

${ }^{27}$ Since data availability differs greatly between countries, the year of the initial value of drop-out rate in primary education varies between countries. However, for most countries, the initial year is 1970 .
} 
access to education and quality of education received, hence lead to reductions in cognitive skills. Cingano (2014) provides support for this channel. The study finds that the main mechanism through which inequality affects growth is by undermining education opportunities for children from poor socio-economic backgrounds, lowering social mobility and hampering skills development. The use of the overall level of income inequality as an instrument hypothesizes an effect of inequality on growth only through its effect on cognitive skills, while inequalities in education and income and growth may be jointly determined. In order to avoid reverse causality, we use the initial level of the Gini coefficient for each country as an instrument ${ }^{28}$.

In Panel B1 we use the governance effectiveness as an instrument while Panel B2 uses initial school drop-out rate for primary education as an instrument. A combination of governance effectiveness, initial school drop-out, and initial years of schooling is used as our instruments in panel B3. Panel B4 uses DALY as an instrument while Panel B5 uses DALY and governance effectiveness as instruments. Final specification uses the overall level of income inequality (measured with Gini index) as an instrument.

In order to obtain comparable effects in terms of standard deviations,we also standardizethe cognitive skills variable in each sub-sample (with a mean equal to 0 and a standard deviation equal to 1). This allows us to directly compare the effect of cognitive skills expressed in terms of standard deviations between sub-samples. Given the large set of results, we only report the coefficient estimate of the cognitive scores variable, the first-stage F-statistic, and the number of countries included in each subsample in brackets, but do not to present the first stage results.

In column 1 of Table 3, in the first two rows, we reproduce results from Tables1and 2 where our cognitive skills variable has a positive and significant impact on economic growth, whether

\footnotetext{
${ }^{28}$ Similarly to drop-out rate, the initial level of Gini coefficient differs between countries. Due to data constraints, the initial year is often around 1980 .
} 
we consider the OLS or the IV estimations. In rows B2 to B6 of the first column IV estimation using different sets of instruments provide coefficient estimates that range between 1.7 and 2.1 and are all larger than the OLS estimate. According to the OLS estimation an increase of one standard deviation in cognitive skills produces an increase in annual economic growth of about 1.5 percentage points. Considering the median value of the IV estimates (1.93\%), the overall effect of cognitive skills is increased by about 27\%. As explained in Madsen (2014) regarding educational achievement, one reason for the increased effect may be the downward bias due to measurement error.

The results in columns 2 to 8 that distinguish between various subsamples provide important insights. Comparing columns 2 and 3 shows that while the effect of cognitive skills is positive and significant for both low and high income countries, both the OLS and IV results indicate that its amplitude is about $60 \%$ higher for the low-income countries. This emphasizes that the promotion of education policies that focus on the quality of education has especially large payoffs in least developed regions. In countries with low levels of education quality, improvements in quality may lead to substantial improvements in productivity of workers. Higher estimated effects of quality on growth in low income countries may be due these productivity gains.

Estimation results by geographical region are presented in columns 4 to $6 .{ }^{29} \mathrm{IV}$ estimates for each region shows a positive and significant impact of cognitive skills on economic growth. We find large effects of cognitive skills on economic growth for Arab States \& Sub-Saharan Africa and Asian countries. Given the important role of skills on growth in these regions, it is possible that low level of cognitive skills may have hindered growth in Africa while the early-period

\footnotetext{
${ }^{29}$ Due to space constraints, we don't present results for European countries. However, results are quite similar to the group of "high income countries" (column 2).
} 
growth explosion of East Asia is may have been due to high level of cognitive skills in this region (Hanushek \& Woessmann, 2016). The lowest coefficient estimates, on the other hand, are obtained for Latin America. As we focus on regions, with much smaller sample sizes, some of the F statistics are now lower than 10. Only in the case of Latin America, however, they are systematically below this threshold. Hence, the results for Latin America should be interpreted with this caveat.

Besides the distinction of countries by economic level and geographical location, we also divided the sample into two parts, in the spirit of Nelson and Phelps (1966). It is possible that countries which are far from the technology frontier, i.e. with low total factor productivity in 1960, will benefit more from an increase in cognitive skills levels than others countries. To test this possibility, we separate the sample by distinguishing low initial total factor productivity (TFP) countries and high initial TFP countries, using the median level of TFP in 1960 (columns 7 and 8). ${ }^{30}$ Results confirm that countries which are far from their technology frontier benefit more from cognitive skills than other countries. Comparing columns 7 and 8, the effect of cognitive skills is doubled for these countries in the standard OLS estimation. When we correct for possible endogeneity, measurement error and omitted variable bias by using the IV GMM estimation technique, the difference between the two groups becomes even larger. Another important finding is that the extent of bias between OLS and IV estimates is the largest for Arab States and Sub-Saharan Africa.This may be due to lower quality of assessments for this region. ${ }^{31}$ In conclusion, our cognitive skills variable is quite stable and in most subsamples has a positive and

\footnotetext{
${ }^{30}$ The group of countries with high TFP differs from the group with high GDP pc, although a high correlation is found (around 0.6). For instance, countries like Colombia, Cyprus or Greece are among the high GDP pc countries, while they do not appear in the group of high TFP countries.

${ }^{31}$ Contrary to other assessments where modern psychometric procedures were included, the PASEC assessment had no Rasch scaling of scores which may reduce survey quality and explain why the estimated IV coefficient is higher than the one found with OLS technique. See Wagner (2011).
} 
significant impact on economic growth. We find that the magnitude of the effect is higher for the low-income countries and for countries with low initial TFP. Across regions, investing in the quality of education appears to be most rewarding for Arab States and Sub-Saharan African countries.

\subsection{The ingredients of growth: innovators and/or imitators?}

In Tables 1 to 3, our updated cognitive skills indicators were included as mean scores, without any focus on the within country distribution of cognitive skills. However, it is important to question whether the top-performers and those reaching a minimum level have different impacts on economic growth. There are two main views regarding the channel through which education enhances growth. The first view argues for investinging the top performers who would boost innovation (Nelson and Phelps, 1966; Aghion and Howitt, 1998; Vandenbussche, Aghion, and Meghir, 2006; Galor, 2011) whilethe alternative view argues for a more egalitarian school system to ensure well-educated masses (Mankiw, Romer \& Weil, 1992). Aghion and Cohen (2004) distinguish economies of imitation from economies of innovation. The first group of economies, that includes low and middle income countries, must invest primarily in the school levels supporting the imitation and implementation of new techniques, that is to say, primary and secondary education. In order to encourage economic growth, the second group of countries must contribute to technological innovation and have at their disposal a large mass of skilled labor. This justifies a major investment in higher education supporting economic growth. The developed countries belong to this second group of economies. These alternative views are reflected in different policy goals such as the Bologna Process that aims at developing high quality standards in the education sectors for European countries and “Education 2030” objective 
that aims to provide the majority of pupils with a minimum level in both mathematics and reading (UNESCO, 2015). Our updated dataset provides an opportunity to address the question of how to allocate education resources between the lowest and the highest achievers.

Altinok et al. (2014) distinguishes between “advanced level students” and "minimum level students" that allow us to test the effects of attaining minimum skill levels and reaching advanced level skills on economic growth. In this dataset, the minimum level threshold is 400 test-score points in the adjusted international scale, while the advanced level threshold is defined as 600 points. The minimum level can be benchmarked to level 1 of PISA assessment where students can answer questions involving familiar contexts where all relevant information is present and the questions are clearly defined (OECD, 2013). These students may be able to perform mathematical tasksquickly, such as reading a single value from a well-labeled table. The international median of this share of students is 73\%, ranging from Malawi with $20 \%$ to Republic of Korea and Chinese Taipei with 95\%. The "advanced level”, on the other hand,is approximately anchored to level 5 of the PISA scale, where students can develop and work with models for complex situations, identifying constraints and specifying assumptions (OECD, 2013). They can select, compare, and evaluate appropriate problem-solving strategies for working with complex problems related to these models. The international median of this share of students is $11 \%$ in our sample, ranging from less than $0.7 \%$ (El Salvador) to 63\% (Korea).

The correlation rate between the share of pupils reaching advanced and minimum levels is not perfect, although it is still quite high $(r=0.82)$, indicating that these differences are not fully comparable to a standard deviation. However, the correlation between the mean score of cognitive skills and the share of pupils reaching the minimum level is higher $(r=0.96)$ than its correlation with the advanced level $(r=0.87)$. Figure 1 presents the relationship between the 
shares of pupils reaching each level, suggesting the existence of an inverted U-shaped relationship. It is indeed possible to achieve relatively high median performance, both with a relatively equitable spread (e.g. Republic of Korea, Finland) and a relatively unequal spread (e.g. Belgium, Switzerland). The same is true for the developing countries with low average performance, as shown by the contrast between Mauritius' higher inequality and Thailand's much greater equality between low and high achievers (Figure 1).

We firstly conduct a simple OLS estimation for the whole sample by including both distributional measures of cognitive skills (see Appendix Table A.7). Both distributional measures of cognitive skills are significantly related to economic growth, when entered either individually or jointly (columns 1-3). Estimates in column 3indicate that a 10 percentage point increase in the share of students reaching the minimum level is associated with 0.4 percentage points higher annual growth, while a 10 percentage point increase in the share of advanced level students is associated with 0.2 percentage points higher annual growth. Expressed in standard deviations, increasing each share by roughly half a standard deviation (8 percentage points for “advanced level” performing share and 13 percentage points for "minimum level” performing share) yields a quite similar growth effect of roughly 0.3 percentage points. We also try alternative specifications in order to test for robustness (columns 4 to 9).In most specifications both measures remain significant, although there is some evidence that the advanced level benchmark may be linked to institutional measures (column 4).

Similarly to the results presented in Table 1, above results may suffer from endogeneity bias. ${ }^{32}$ We address this endogeneity issue and explore the effects of basic and advanced

\footnotetext{
${ }^{32}$ For example, while high economic growth may enable developed countries to invest in high quality universities and boost the share of pupils reaching the advanced level, in developing country contexts it may boost investments in primary and secondary schools, allowing more pupils to achieve the minimum level.
} 
performers in greater depth by using different subsamples. In Table 4, we conduct an analysis similar to Table 3 for both advanced and basic performers. While in panel A standard OLS estimations are presented, Panel B provides IV-GMM estimates that correct for measurement error and endogeneity. In all estimations, both the top performers share and the basic literacy share are included. Given these two endogenous variables, we need at least two instruments for identification. To test robustness of our results, we provide four separate IV-GMM estimates in panels B1-B4 where each panel uses a different set of instruments. Governance effectiveness (GE) and DALY, which are powerful predictors for cognitive skills, are common instruments across these panels. In addition to these instruments, panel B1 uses initial years of education, panel B2 uses initial years of education and drop out of primary education, panel B3 uses survival rate to the last grade of primary education, panel B4 uses initial years of schooling and initial level of Gini index as instruments. Controlling for endogeneity, IV-GMM estimates for the whole sample (column 1) provide quite stable coefficients for both advanced and minimum levels indicating a positive and significant effect of basic performers but an insignificant effect for advanced performers.

Above results for the overall sample may be hiding heterogeneity in the impact of skills on growth. The basic performers may be essential component of growth in developing countries as imitators while advanced performers may be crucial for innovation that spurs growth in developed countries. In order to test this hypothesis, countries are separated according to their economic level in columns 2 and 3. All IV estimates for high income countries (col. 2) indicate that advanced level of cognitive skills is an important factor of economic growth for high-income countries. The coefficient estimate for the share of minimum performers, however, is marginally significant only in two of four IV panels and the magnitude of the coefficient is much lower than 
that for advanced performers. For low income countries in column 3, we get the opposite result that minimum performers enhance growth more than advanced performers. This suggests that developing countries which focus on the provision of mass education may grow faster than other developing countries that mainly provide subsidies for elites.

Since our dataset includes a significant number of developing countries, we provide more detailed analysis by distinguishing between three regions (Arab states and Sub-Saharan Africa (SSA); Asia; and Latin America). The results are presented in columns 4 to 6 . While the share of students with a minimum level of cognitive skills have the greatest impact on economic growth in Arab states and SSA, we find the exact opposite effect for Latin American countries, confirming the previous results of Hanushek \& Woessmann (2012b). In Arab states and SSA countries, in all estimations, the share of top performers has a negative effect on economic growth. This result should be viewed with caution, because the share of top performers in most countries of this region is very low and the first-stage F-statistics are rather low. The results for Latin America should also be treated with caution since in most estimations, we face a weak instrument problem. In panel B4, where the instruments appear to be relevant, the effect of the share of top performers is positive and significant. Another important result concerns Asian countries. While in the OLS estimation, both measures of cognitive skills have a positive and significant effect on economic growth, the IV estimates show that only the share of pupils reaching the basic level enhances economic growth. The different conclusions from the OLS and IV estimates regarding the role of top performers may be stemming from a reverse causality problem: countries with higher economic growth may be investing more on the education of pupils with high skills. Above results suggest that channeling educational investments to different sub-populations is likely to yield different growth rates depending on the economic level of 
countries. These results should, however, be also tested in a panel data setting in order to test to what extent an increase of the share of advanced (minimum) level students enhances economic growth.

\section{Conclusion}

Among all the explanations for economic growth, one that is generally accepted concerns the level of human capital. The seeming obviousness of the idea, however, has met with inconsistencies in the existing literature as many macro-economic analyses failed to find a positive relationship between education and growth. Pritchett (2001) showed that very often the impact of education on growth is negative and significant. However, the majority of the studies in the literature have ignored the qualitative dimension of human capital, recognizing only the purely quantitative indicators.

The use of national or international achievement tests in mathematics and sciences fills this gap in qualitative measurement. Hanushek and Kimko (2000), Barro (2001) and Hanushek and Woessmann (2012a) used qualitative variables, but did not exploit all of the international assessments or all the countries surveyed (respectively 36, 43 and 50 countries included in their samples). In this paper, we use an updated dataset on cognitive skills for a significantly larger number of countries (85 countries). Consequently, our sample includes more developing countries than the previous studies and the time span is longer since we include the most recent assessments.

In its study of the skills and growth relationship previous studies mainly focuses on the average effect across countries and rarely consider heterogeneous effects. This study aims to fill 
in this gap in the literature. Using a much richer data set the main objective of the paper is to test for heterogeneity in the estimated effect of education on economic growth in addition to its average effect. For this purpose, we provide estimates separately by (i) income level of countries, (ii) regions, and (iii) total factor productivity. We also conduct an analysis that tests whether the effect of minimum and advanced level of cognitive skills varies between countries. This analysis aims at answering which types of skills matter most for the economic growth of less developed and more developed regions. Throughout the analysis we control for potential endogeneity and measurement error by using an IV-GMM estimation strategy that is based on various instruments proposed in the literature so far. Thus, this paper provides the first comprehensive study in the literature that assesses within a causal framework the differences in the amplitude of cognitive skills and growth relationship. The paper also tests the robustness of the estimated impact of cognitive skills on economic growth to different estimation strategies and subsamples.

Our analysis yields four main results. i) While we cannot find a robust effect of the quantity of schooling (measured as initial years of education), the coefficient associated with our updated cognitive skills variable is quite strong over most estimations. These results confirm those reported by HW. ii) Our results show that including more developing countries increases the overall impact of cognitive skills on economic growth by about 27\%. iii) Moreover, we find that the magnitude of the effect is about $60 \%$ higher for low-income countries compared to highincome countries, more than doubles when low TFP countries are compared to high TFP countries. There are also marked differences across geographic regions. iv) Lastly, a focus on the share of basic and top performers within each country highlights different effects between subsamples. While in high-income countries the share of top performers in student achievement tests has a strong and positive effect on economic growth, it is the share of students reaching the 
minimum level which has the most impact on economic growth for countries from Arab States and Sub-Saharan Africa. These results highlight the importance of distinguishing between countries to get a more comprehensive picture of the relationship between education and growth. 


\section{References}

Acemoglu, D. and Zilibotti, F. 2001. Productivity Differences. Quarterly Journal of Economics. 116(2), 563-606.

Adams-Kane, J., \& Lim, J. J. 2014. Institutional quality mediates the effect of human capital on economic performance.World Bank Policy Research Working Paper 6792, Washington.

Aghion P. and Cohen E., 2004. Éducation et Croissance. La Documentation française,Paris, 2004.

Aghion P. and Howitt P., 1998. Endogeneous Growth Theory. MIT Press, Cambridge.

Altinok, N., Diebolt, C. \& de Meulemeester, J.-L. 2014. A New International Database on Education Quality: 1960-2010. Applied Economics 46 (11), 1212-1247.

Altinok, N., \& Murseli, H. 2007. International database on Human Capital Quality. Economics Letters 96 (2), 237-244.

Barro, R. 1991. Economic growth in a cross-section of countries. Quarterly Journal of Economics 106 (2), 407-443.

Barro, R.J. 2001. Education and Economic Growth. in Helliwell, J.F. (Ed.), The Contribution of Human and Social Capital to Sustained Economic Growth and Well-Being (pp. 14-41). Paris: OECD Press.

Barro, R.J., \& Lee, J.W. 1993. International Comparisons of Educational Attainment. Journal of Monetary Economics 32, 363-394.

Barro, R.J., \& Lee, J.W. 2010. New Data Set of Educational Attainment in the World: 19502010, NBER Working Paper 15902.

Barro, R.J., \& Lee, J.W. 2013. A new data set of educational attainment in the world, 19502010. Journal of Development Economics 104, 184-198.

Baum, C.F., M.E. Schaffer, \& Stillman, S. 2003. Instrumental Variables and GMM: Estimation and Testing. The Stata Journal 3, , 1-31.

Bils, M., \& Klenow, P. J. 2000. Does schooling cause growth?. American Economic Review, 1160-1183.

Breton, T.R. 2011. The quality vs. the quantity of schooling: What drives economic growth?. Economics of Education Review 30 (4), 765-773.

Breton, T.R. 2015. High Test Scores or More Schooling? Another Look at the Causes of Economic Growth. Journal of Human Capital. 9(2), 239-263.

Castelló-Climent, Amparo and Ana Hidalgo-Cabrillana 2012. The role of educational quality and quantity in the process of economic development, Economics of Education Review, vol. 31(4), 391-409.

Chinapah, V. 2003. Monitoring Learning Achievement (MLA) Project in Africa. Association for the Development of Education in Africa (ADEA). Paris: International Institute for Educational Planning.

Coulombe, S., \& Tremblay, J.-F. 2006. Literacy and Growth. The B.E. Journal of Macroeconomics 6(2), 1-34. 
Cohen, D., \& Soto, M. 2007. Growth and human capital: good data, good results. Journal of Economic Growth 12 (1), 51-76.

Corak, M., 2013. Income Inequality, Equality of Opportunity, and Intergenerational Mobility. Journal of Economic Perspectives, 27, no. 3, 79-102.

Durlauf, S.N., Johnson, P.A., \& Temple, J.R. 2005. Growth econometrics. Handbook of economic growth 1, 555-677.

Easterly, W., \& Levine, R. 1997. Africa's growth tragedy: policies and ethnic divisions. The Quarterly Journal of Economics, 1203-1250.

Fuller, W.A. 1977. Some properties of a modification of the limited information estimator. Econometrica 45(4), 939-954.

Glaeser, E.L., La Porta, R., Lopez-de-Silanes, F., \& Shleifer, A. 2004. Do institutions cause growth?. Journal of Economic Growth 9 (3), 271-303.

Glewwe, P., Maïga, E., \& Zheng, H. 2014. The Contribution of Education to Economic Growth: A Review of the Evidence, with Special Attention and an Application to Sub-Saharan Africa. World Development 59, 379-393.

Goldstein, H. 1993. Interpreting international comparisons of student achievement. Report Prepared for UNESCO, Paris.

Guernier, V., Hochberg, M. E., \& Guégan, J. F. 2004. Ecology drives the worldwide distribution of human diseases. PLoS biology 2 (6), e141.

Hahn, J., Hausman, J. A., \& Kuersteiner, G. 2004. Estimation with weak instruments: Accuracy of higher-order bias and MSE approximations. Econometrics Journal, 7(1), 272-306.

Hall, R.E., Jones, C.I., 1999. Why do some countries produce so much more output per worker than others? Quarterly Journal of Economics, 114 (1), 83-116.

Hanushek, E.A., \& Kimko, D.D. 2000. Schooling, labor-force quality, and the growth of nations. American Economic Review, 1184-1208.

Hanushek, E.A. 2002. Publicly provided education. In A. J. Auerbach \& M. Feldstein (Eds.), Handbook of Public Economics. (pp. 2045-2141). Amsterdam: Elsevier.

Hanushek, E., Lavy, V. \& Hitomi, K. 2006. Do students care about school quality? Determinants of dropout behavior in developing countries, Journal of Human Capital, 2008, vol. 2, no. 1, p. 69-105.

Hanushek, E.A., \& Woessmann, L. 2011. The economics of international differences in educational achievement. In E. A. Hanushek, S. Machin, \& L. Woessmann (Eds.), Handbook of the Economics of Education, Vol. 3 (pp. 89-200). Amsterdam: North Holland.

Hanushek, E.A., \& Woessmann, L. 2012a. Do Better Schools Lead to More Growth? Cognitive Skills, Economic Outcomes, And Causation. Journal of Economic Growth 17(4), 267321.

Hanushek, E. A., \& Woessmann, L. 2012b. Schooling, educational achievement, and the Latin American growth puzzle. Journal of Development Economics 99 (2), 497-512.

Hanushek, E. A., \& Woessmann, L. 2015. The Knowledge Capital of Nations. Education and the Economics of Growth. The MIT Press, Cambridge, MA. 
Hanushek, E. A., \& Woessmann, L. 2016. Knowledge capital, growth, and the East Asian miracle. Science, 351(6271), 344-345.

Hanushek, E.A. 2013. Economic growth in developing countries: The role of human capital. Economics of Education Review 37, 204-212.

Hanushek, E.A., Schwerdt, G., Wiederhold, S., Woessmann, L. 2015. Returns to Skills around the World: Evidence from PIAAC. European Economic Review 73, 103-130.

Heckman, J. and E. Vytlacil, 2007. "Econometric evaluation of social programs, part I: Causal models, structural models and econometric policy evaluation," Handbook of Econometrics Volume 6B. J. Heckman and E. Leamer, eds. 4779-4874.

Heston, A., Summers, R., \& Aten, B. 2002. Penn world tables. Center for International Comparisons at the University of Pennsylvania.

Inter-American Development Bank. 1999. Facing up to Inequality in Latin America: Economic and Social Progress in Latin America, 1998-99 Report.Johns Hopkins University Press.

Islam, R., Ang, J. B., \& Madsen, J. B. 2014. Quality-Adjusted Human Capital and Productivity Growth. Economic Inquiry 52 (2), 757-777.

Kaufmann, D., Kraay, A., \& Mastruzzi, M. 2011. The worldwide governance indicators: methodology and analytical issues. Hague Journal on the Rule of Law 3 (02), 220-246.

Keeves, J.P.1992. The IEA Science Study III: Changes in Science Education and Achievement: 1970 to 1984. Oxford: Pergamon Press.

Krueger, A., 2012. “'The Rise and Consequences of Inequality in the United States,' Speech at the Center for American Progress, Washington,DC, January 12, 2012.

Lee, J. W., \& Barro, R. J. 2001. Schooling quality in a cross-section of countries. Economica 68 (272), 465-488.

Levine, R., \& Renelt, D. 1992. A sensitivity analysis of cross-country growth regressions. The American Economic Review, 942-963.

Mankiw, N. G., Romer, D., \& Weil, D. N. 1992. A contribution to the empirics of economic growth (No. w3541). National Bureau of Economic Research.

Mellinger, A., Sachs, J.D. and Gallup, J. 2000. Climate, coastal proximity, and development. In Oxford Handbook of Economic Geography, ed. G.L. Clark, M.P. Feldman and M.S. Gertler. New York: Oxford University Press.

McLean, L. 1990. Let's call a halt to pointless testing, Education Canada, 30(3), 10-13.

Nelson R. and Phelps E., 1966. Investment in Humans, Technological Diffusion andEconomic Growth. American Economic Review, 61, 69-75.

OECD. 2013. PISA 2012 Results: What Students Know and Can Do - Student Performance in Mathematics, Reading and Science (Volume 1), PISA, OECD Publishing.

Cingano, F. (2014), “Trends in Income Inequality and itsImpact on Economic Growth”, OECD Social, Employment andMigration Working Papers, No. 163, OECD Publishing. 
Pritchett, L. 2001. Where has all the education gone?. The World Bank Economic Review 15 (3), 367-391.

Ramirez, F. O., Luo, X., Schofer, E., \& Meyer, J. W. 2006. Student achievement and national economic growth. American Journal of Education 113 (1), 1-29.

Robitaille, D.F. \& Garden, R.A. (Eds.).1989. The IEA Study of Mathematics II: Context and Outcomes of School Mathematics. Oxford: Pergamon Press.

Rodrik, Dani. 2002. "Institutions, Integration, and Geography: In Search of the Deep Determinants of Economic Growth”. Copy at http://www.tinyurl.com/nccl2fd

Rotberg, I.C. (1990). I never promised you first place. Phi Delta Kappan, 72, 296-303.

Sachs, J. D. 2001. Tropical underdevelopment (No. w8119). National Bureau of Economic Research.

Sala-i-Martin, X., Doppelhofer, G., \& Miller, R.I. 2004. Determinants of long-term growth: A Bayesian Averaging of Classical Estimates (BACE) approach. American Economic Review 94 (4), 813-835.

Sala-i-Martin, X. X. 1997. I just ran four million regressions (No. w6252). National Bureau of Economic Research.

Stock, J.H., Wright, J.H., and Yogo, M. 2002. A Survey of Weak Instruments and Weak Identification in Generalized Method of Moments, Journal of Business and Economic Statistics, 20(4), 518-29.

UNESCO. 2000. With Africa for Africa. Toward quality education for all. UNESCO. Paris: Human Sciences Research Council.

UNESCO. 2015. Education For All 2000-2015: Achievements and Challenges. Paris, UNESCO Publishing.

Wagner, D. 2011. Smaller, Quicker, Cheaper. Improving Learning Assessments for Developing Countries. UNESCO: International Institute of Educational Planning. Paris.

Woessmann, L. 2003. Central exit exams and student achievement: International evidence. In P.E. Peterson \& M. R. West (Eds.), No child left behind? The politics and practice of school accountability (pp. 292-323). Washington D.C.: Brookings Institution Press.

Woessmann, L., Luedemann, E., Schuetz, G., \& West, M. R. 2009. School accountability, autonomy, and choice around the world. Cheltenham, UK: Edward Elgar. 


\section{Figures and Tables}

Figure 1. Relationship between the proportion of pupils reaching the minimum level and the advanced level

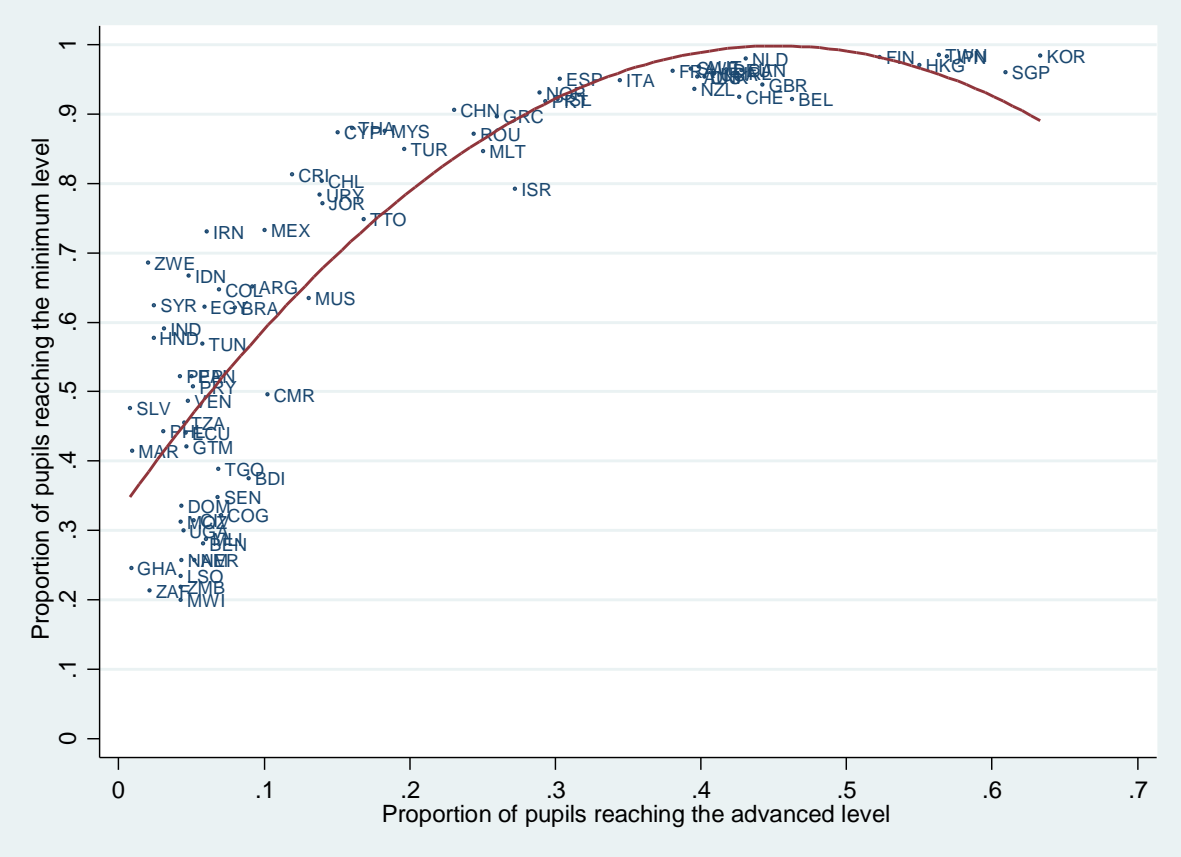


Table 1. Standard estimates of the effect of cognitive skills on economic growth

\begin{tabular}{|c|c|c|c|c|c|c|c|c|c|}
\hline & (1) & $(2)$ & (3) & $(4)^{(a)}$ & $(5)^{(b)}$ & $(6)^{(c)}$ & $(7)^{(d)}$ & $(8)^{(\mathrm{e})}$ & $(9)^{(\mathrm{f})}$ \\
\hline \multicolumn{10}{|c|}{ (A) Data from Hanushek and Woessmann (2012a), sample from Hanushek and Woessmann (2012a) } \\
\hline \multicolumn{2}{|c|}{ Cognitive skills } & $\begin{array}{l}1.238 \\
(8.62)\end{array}$ & $\begin{array}{l}1.199 \\
(7.38)\end{array}$ & $\begin{array}{l}1.224 \\
(6.88)\end{array}$ & $\begin{array}{l}1.102 \\
(8.13)\end{array}$ & $\begin{array}{l}1.006 \\
(3.33)\end{array}$ & $\begin{array}{l}0.853 \\
(5.02)\end{array}$ & $\begin{array}{l}0.594 \\
(5.18)\end{array}$ & $\begin{array}{l}1.191 \\
(6.04)\end{array}$ \\
\hline \multirow[t]{2}{*}{ Years of schooling 1960} & 0.408 & & 0.050 & 0.014 & 0.064 & 0.070 & -0.003 & -0.014 & -0.067 \\
\hline & $(4.41)$ & & $(0.79)$ & $(0.18)$ & $(0.76)$ & $(0.79)$ & $(0.04)$ & $(0.23)$ & $(0.89)$ \\
\hline \multirow[t]{2}{*}{ GDP pс 1960} & -0.399 & -0.294 & -0.321 & -0.300 & -0.317 & -0.270 & -0.334 & -0.315 & -0.975 \\
\hline & $(4.85)$ & $(9.21)$ & $(8.49)$ & $(7.48)$ & $(5.74)$ & (5.10) & (7.18) & $(6.80)$ & $(4.38)$ \\
\hline \multicolumn{10}{|c|}{ (B) Data from updated Altinok et al. (2014), Sample from Hanushek and Woessmann (2012a) } \\
\hline \multirow{2}{*}{\multicolumn{2}{|c|}{ Cognitive skills }} & 1.312 & 1.316 & 1.383 & 1.382 & 1.185 & 1.023 & 0.669 & 1.360 \\
\hline & & $(8.86)$ & $(7.24)$ & $(6.84)$ & (11.13) & $(4.44)$ & $(4.57)$ & $(3.56)$ & $(6.44)$ \\
\hline \multirow[t]{2}{*}{ Years of schooling 1960} & 0.408 & & -0.004 & -0.062 & -0.045 & 0.006 & -0.038 & -0.018 & -0.079 \\
\hline & $(4.41)$ & & $(0.06)$ & $(0.76)$ & (0.69) & $(0.07)$ & $(0.52)$ & $(0.27)$ & (1.11) \\
\hline \multirow[t]{2}{*}{ GDP рс 1960} & -0.399 & -0.319 & -0.317 & -0.294 & -0.301 & -0.243 & -0.327 & -0.314 & -1.171 \\
\hline & $(4.85)$ & $(9.41)$ & $(8.18)$ & $(7.30)$ & (6.29) & (4.19) & (6.73) & $(6.49)$ & $(6.50)$ \\
\hline \multicolumn{10}{|c|}{ (C) Data from updated Altinok et al. (2014), Sample from updated Altinok et al. (2014) } \\
\hline \multirow{2}{*}{\multicolumn{2}{|c|}{ Cognitive skills }} & 1.629 & 1.510 & 1.382 & 1.587 & 1.101 & 1.531 & 0.720 & 1.610 \\
\hline & & $(13.14)$ & $(10.50)$ & $(8.36)$ & $(10.40)$ & $(3.96)$ & $(5.66)$ & $(2.72)$ & $(9.92)$ \\
\hline \multirow[t]{2}{*}{ Years of schooling 1960} & 0.465 & & 0.115 & 0.168 & 0.099 & 0.149 & 0.055 & 0.003 & 0.036 \\
\hline & $(4.90)$ & & $(1.83)$ & $(2.51)$ & $(1.29)$ & $(2.28)$ & $(0.83)$ & $(0.06)$ & $(0.54)$ \\
\hline \multirow[t]{2}{*}{ GDP pс 1960} & -0.220 & -0.270 & -0.310 & -0.315 & -0.294 & -0.314 & -0.281 & -0.308 & -1.073 \\
\hline & $(3.82)$ & $(9.43)$ & $(8.21)$ & (8.63) & (7.29) & (7.18) & (6.37) & $(6.84)$ & $(7.41)$ \\
\hline (A) Observations & 50 & 50 & 50 & 50 & 52 & 50 & 47 & 45 & 50 \\
\hline (B) Observations & 50 & 50 & 50 & 50 & 52 & 50 & 47 & 45 & 50 \\
\hline (C) Observations & 84 & 84 & 80 & 80 & 85 & 80 & 68 & 68 & 80 \\
\hline (A) R-squared (adj.) & 0.313 & 0.753 & 0.756 & 0.754 & & 0.778 & 0.800 & 0.803 & 0.667 \\
\hline (B) R-squared (adj.) & 0.313 & 0.792 & 0.792 & 0.794 & & 0.823 & 0.820 & 0.791 & 0.760 \\
\hline (C) R-squared (adj.) & 0.232 & 0.719 & 0.729 & 0.739 & & 0.756 & 0.714 & 0.750 & 0.670 \\
\hline \multicolumn{10}{|c|}{$\begin{array}{l}\text { Notes: Dependent variable: average annual growth rate in GDP per capita, 1960-2000 for sample from Hanushek and Woessma } \\
\text { from updated Altinok et al. (2014). Regressions include a constant. Test scores are average of math and science, primary through } \\
\text { through lower-secondary school (for Altinok et al. data), all years. Absolute t-statistics in parentheses } \\
\text { (a) Mean years of schooling refers to the average between } 1960 \text { and } 2000 \text { (HW data), } 2010 \text { (ADM data). } \\
\text { (b) Robust regression including the two outliers of Botswana and Nigeria (with rreg robust estimation implemented in Stata). } \\
\text { (c) Specification includes dummies for the eight world regions taken in HW. } \\
\text { (d) Specification includes additional controls for openness and property rights } \\
\text { (e) Specification includes additional controls for openness, property rights, fertility, and tropical location. } \\
\text { (f) GDP per capita } 1960 \text { measured in logs }\end{array}$} \\
\hline
\end{tabular}


Table 2. From schooling institutions to education quality to economic growth: instrumental variables estimates

\begin{tabular}{|c|c|c|c|c|c|c|c|c|c|}
\hline & $(1)$ & $(2)$ & (3) & $(4)$ & $(5)$ & $(6)^{(a)}$ & $(7)^{(b)}$ & $(8)$ & $(9)$ \\
\hline \multicolumn{10}{|l|}{ Second stage } \\
\hline \multicolumn{10}{|l|}{ GMM } \\
\hline Cognitive skills & $\begin{array}{l}1.913 \\
(9.74)\end{array}$ & $\begin{array}{l}1.898 \\
(9.09)\end{array}$ & $\begin{array}{l}2.012 \\
(5.47)\end{array}$ & $\begin{array}{l}1.986 \\
(5.06)\end{array}$ & $\begin{array}{l}1.938 \\
(11.03)\end{array}$ & $\begin{array}{l}1.866 \\
(5.82)\end{array}$ & $\begin{array}{l}2.203 \\
(11.25)\end{array}$ & $\begin{array}{l}1.897 \\
(11.02)\end{array}$ & $\begin{array}{l}1.875 \\
(10.45)\end{array}$ \\
\hline $\begin{array}{l}\text { Fuller(1) modification of LIML } \\
\text { Cognitive skills }\end{array}$ & $\begin{array}{l}1.905 \\
(9.87)\end{array}$ & $\begin{array}{l}1.889 \\
(9.24)\end{array}$ & $\begin{array}{l}2.090 \\
(5.60)\end{array}$ & $\begin{array}{l}2.061 \\
(5.19)\end{array}$ & $\begin{array}{l}1.927 \\
(11.08)\end{array}$ & $\begin{array}{l}1.886 \\
(5.99)\end{array}$ & $\begin{array}{l}2.165 \\
(10.97)\end{array}$ & $\begin{array}{l}1.900 \\
(11.06)\end{array}$ & $\begin{array}{l}1.864 \\
(10.51)\end{array}$ \\
\hline \multicolumn{10}{|l|}{$\begin{array}{l}\text { First stage (dependent variable: } \\
\text { Cognitive skills) }\end{array}$} \\
\hline DALY & $\begin{array}{l}-0.323 \\
(6.27)\end{array}$ & & $\begin{array}{l}-1.556 \\
(5.14)\end{array}$ & $\begin{array}{l}-1.408 \\
(4.48)\end{array}$ & $\begin{array}{l}-0.272 \\
(6.19)\end{array}$ & $\begin{array}{l}-3.089 \\
(3.24)\end{array}$ & $\begin{array}{l}-0.238 \\
(5.11)\end{array}$ & $\begin{array}{l}-0.237 \\
(5.09)\end{array}$ & \\
\hline Initial years of schooling & & & & $\begin{array}{l}0.046 \\
(1.32)\end{array}$ & $\begin{array}{l}0.146 \\
(3.60)\end{array}$ & $\begin{array}{l}0.003 \\
(0.09)\end{array}$ & $\begin{array}{l}0.175 \\
(3.13)\end{array}$ & & $\begin{array}{l}0.146 \\
(3.37)\end{array}$ \\
\hline Early Death Rates (EDR) & & $\begin{array}{l}-10.173 \\
(5.56)\end{array}$ & $\begin{array}{l}42.883 \\
(4.24)\end{array}$ & $\begin{array}{l}38.290 \\
(3.62)\end{array}$ & & & & & \\
\hline Governance effectiveness & & & & & & & & $\begin{array}{l}0.514 \\
(5.69) \\
\end{array}$ & $\begin{array}{l}0.637 \\
(7.30) \\
\end{array}$ \\
\hline No. of countries & 78 & 78 & 78 & 78 & 78 & 27 & 51 & 77 & 79 \\
\hline First-stage F-statistic & 47.00 & 30.91 & 39.43 & 37.47 & 35.55 & 5.31 & 26.41 & 50.71 & 42.62 \\
\hline $\begin{array}{l}\text { Sargan statistic } \\
\text { p-value }\end{array}$ & & & $\begin{array}{l}1.764 \\
(0.184)\end{array}$ & $\begin{array}{l}1.932 \\
(0.165)\end{array}$ & $\begin{array}{l}0.078 \\
(0780)\end{array}$ & $\begin{array}{l}0.428 \\
(0.513)\end{array}$ & $\begin{array}{l}0.433 \\
(0510)\end{array}$ & $\begin{array}{l}0.035 \\
(0852)\end{array}$ & $\begin{array}{l}0.219 \\
(0640)\end{array}$ \\
\hline $\begin{array}{l}\text { Durbin-Wu-Haussman } X^{2} \text { test } \\
\text { p-value }\end{array}$ & $\begin{array}{l}3.900 \\
(0.048)\end{array}$ & $\begin{array}{l}2.960 \\
(0.085)\end{array}$ & $\begin{array}{l}0.666 \\
(0.414)\end{array}$ & $\begin{array}{l}0.497 \\
(0.481)\end{array}$ & $\begin{array}{l}7.089 \\
(0.008)\end{array}$ & $\begin{array}{l}0.580 \\
(0.447)\end{array}$ & $\begin{array}{l}7.139 \\
(0.008)\end{array}$ & $\begin{array}{l}5.878 \\
(0.015)\end{array}$ & $\begin{array}{l}3.567 \\
(0.058)\end{array}$ \\
\hline
\end{tabular}


Table 3.Effects of cognitive skills on economic growth by economic level of countries and regions

\begin{tabular}{|c|c|c|c|c|c|c|c|c|}
\hline & (1) & (2) & (3) & (4) & (5) & (6) & (7) & (8) \\
\hline & All countries & $\begin{array}{l}\text { High Income } \\
\text { Countries }^{(a)}\end{array}$ & $\begin{array}{l}\text { Low Income } \\
\text { Countries }^{(a)}\end{array}$ & $\begin{array}{l}\text { Arab States \& } \\
\text { Sub-Saharan } \\
\text { Africa }\end{array}$ & $\begin{array}{l}\text { Asian } \\
\text { Countries }\end{array}$ & $\begin{array}{l}\text { Latin } \\
\text { American } \\
\text { Countries }\end{array}$ & $\begin{array}{l}\text { High TFP } \\
\text { countries }\end{array}$ & $\begin{array}{l}\text { Low TFP } \\
\text { countries }\end{array}$ \\
\hline \multicolumn{9}{|l|}{ A- OLS } \\
\hline \multirow[t]{2}{*}{ Cognitive skills } & 1.510 & 0.899 & 1.600 & 0.892 & 1.710 & -0.062 & 0.917 & 1.836 \\
\hline & $(10.50)$ & $(7.68)$ & $(8.18)$ & $(2.96)$ & $(16.22)$ & $(0.23)$ & $(7.83)$ & $(12.68)$ \\
\hline Adj. $R^{2}$ (Observations) & $0.729(80)$ & $0.717(40)$ & $0.765(40)$ & $0.424(25)$ & $0.958(14)$ & $0.524(17)$ & $0.627(36)$ & $0.858(36)$ \\
\hline \multicolumn{9}{|l|}{ B1- IV-GMM } \\
\hline \multirow[t]{2}{*}{ Cognitive skills } & 1.875 & 1.306 & 1.833 & 2.500 & 1.236 & 0.542 & 0.956 & 2.483 \\
\hline & $(10.45)$ & $(8.12)$ & $(10.16)$ & $(2.26)$ & $(5.30)$ & $(1.71)$ & $(5.55)$ & $(10.15)$ \\
\hline F statistic (observations) & $42.62(79)$ & $29.46(39)$ & $19.33(40)$ & $1.56(25)$ & $13.27(14)$ & $7.06(17)$ & $16.61(35)$ & $16.49(36)$ \\
\hline \multicolumn{9}{|l|}{ B2- IV-GMM } \\
\hline \multirow[t]{2}{*}{ Cognitive skills } & 2.051 & 1.225 & 2.074 & 1.886 & 1.650 & 1.497 & 0.740 & 2.214 \\
\hline & $(9.80)$ & $(7.11)$ & $(9.87)$ & $(4.20)$ & (6.19) & $(2.43)$ & $(2.33)$ & $(9.56)$ \\
\hline F statistic (observations) & $27.51(74)$ & $13.76(35)$ & $9.45(35)$ & $6.87(25)$ & $4.97(11)$ & $1.97(17)$ & $5.16(30)$ & $9.75(36)$ \\
\hline \multicolumn{9}{|l|}{ B3- IV-GMM } \\
\hline \multirow{2}{*}{ Cognitive skills } & 1.994 & 1.254 & 2.064 & 1.965 & 1.743 & 0.423 & 0.932 & 2.410 \\
\hline & $(10.12)$ & $(7.70)$ & $(10.69)$ & $(4.57)$ & $(7.42)$ & $(2.08)$ & $(4.08)$ & $(10.89)$ \\
\hline F statistic (observations) & $27.80(73)$ & $21.23(34)$ & $11.17(39)$ & $6.28(25)$ & $4.79(11)$ & $4.36(17)$ & $12.70(29)$ & $13.52(36)$ \\
\hline \multicolumn{9}{|l|}{ B4- IV-GMM } \\
\hline \multirow[t]{2}{*}{ Cognitive skills } & 1.938 & 1.258 & 1.963 & 1.843 & 1.630 & 1.128 & 0.839 & 2.352 \\
\hline & (11.03) & $(6.91)$ & $(12.02)$ & $(5.43)$ & $(8.37)$ & $(2.23)$ & $(5.57)$ & (11.88) \\
\hline F statistic (observations) & $35.55(78)$ & $9.14(39)$ & $16.66(39)$ & $11.82(25)$ & $6.29(12)$ & $4.02(17)$ & $40.62(34)$ & $14.37(36)$ \\
\hline \multicolumn{9}{|l|}{ B5- IV-GMM } \\
\hline \multirow[t]{2}{*}{ Cognitive skills } & 1.912 & 1.209 & 1.966 & 1.883 & 1.635 & 0.534 & 0.821 & 2.439 \\
\hline & $(11.38)$ & $(8.29)$ & $(12.05)$ & $(5.79)$ & $(9.74)$ & $(1.78)$ & $(6.78)$ & $(12.22)$ \\
\hline F statistic (observations) & $37.26(77)$ & $8.79(38)$ & $16.95(39)$ & $8.50(25)$ & $24.44(12)$ & $4.24(17)$ & $64.67(33)$ & $13.30(36)$ \\
\hline \multicolumn{9}{|l|}{ B6- IV-GMM } \\
\hline \multirow[t]{2}{*}{ Cognitive skills } & 1.712 & 0.954 & 1.779 & 0.773 & 0.912 & 1.476 & 1.085 & 2.073 \\
\hline & $(10.95)$ & $(8.17)$ & $(10.84)$ & $(1.93)$ & (3.28) & $(2.27)$ & $(6.49)$ & $(10.07)$ \\
\hline F statistic (observations) & $33.24(78)$ & $29.37(38)$ & $13.45(40)$ & $9.40(25)$ & $9.84(14)$ & $2.04(17)$ & $21.69(36)$ & $11.43(34)$ \\
\hline
\end{tabular}

Notes: Dependent variable: average annual growth rate in GDP per capita, 1960-2010 for sample from updated Altinok et al. (2014). Regressions include a constant. Test scores are average of math and science, primary through lower secondary school, all years. Absolute t-statistics in parentheses. Each panel with IV estimations includes different instruments but always initial years of schooling (hereafter Yrs). B1: Yrs + governance effectiveness. B2: Yrs + drop out of primary education. B3: Yrs + governance effectiveness + drop out of primary education B4: Yrs + DALY. B5: Yrs + governance effectiveness + DALY. B6: Yrs + initial level of Gini index

${ }^{(a)}$ Countries above/below sample median of GDP per capita 1960 
Table 4.Effects of advanced and minimum levels of cognitive skills on economic growthacross subsamples

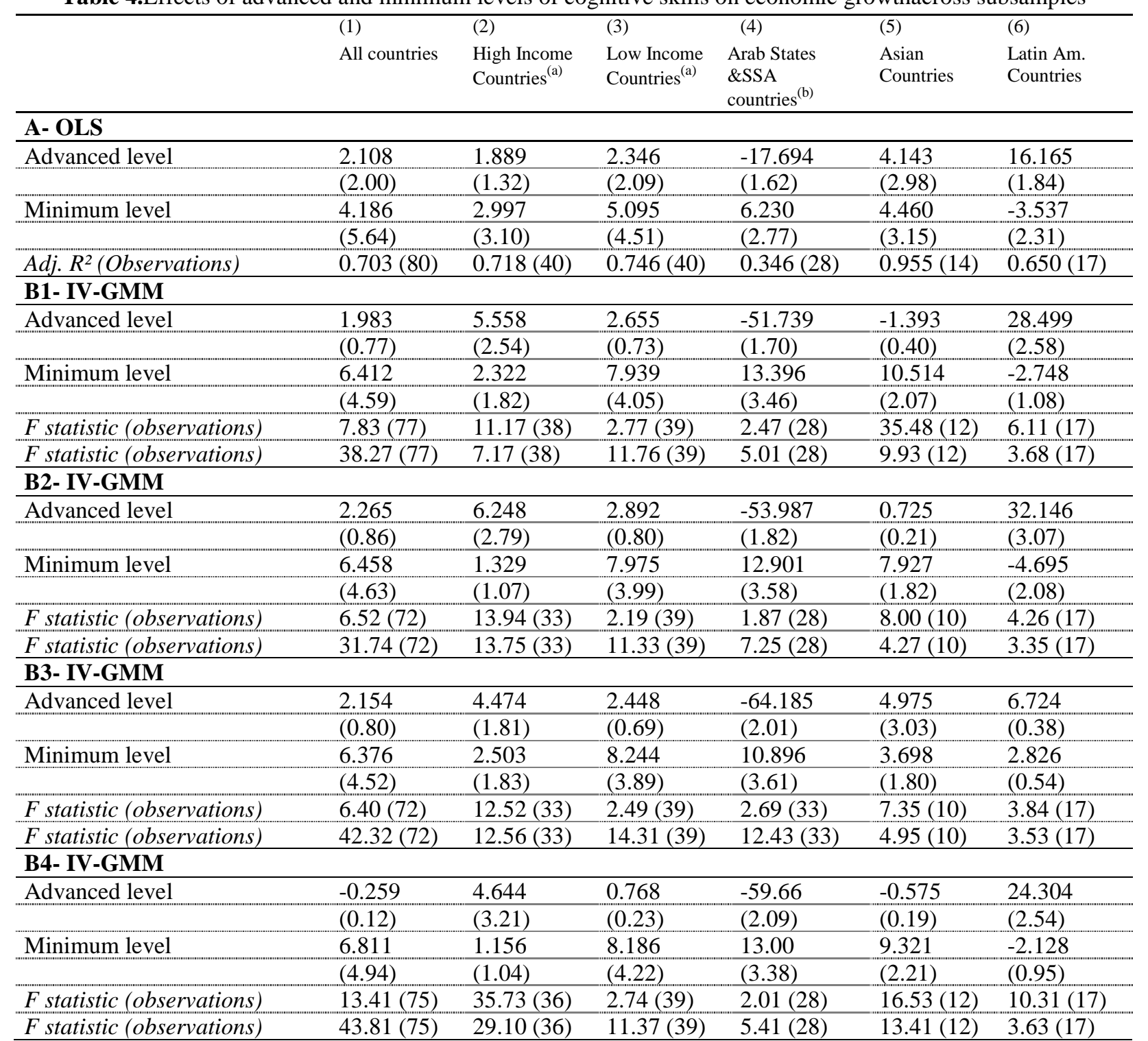

Notes: Dependent variable: average annual growth rate in GDP per capita, 1960-2010. Regressions include a constant. Independent variables include the share of pupil reaching the advanced leve ("Advanced Level") or the minimum level ("Minimum Level"). Absolute t-statistics in parentheses. Each panel with IV estimations includes different instruments but always governance effectiveness (GE) and DALY which are powerful predictors for cognitive skills. B1: GE + DALY + initial years of education. B2: GE + DALY + initial years of education + drop out of primary education. B3: GE + DALY + survival rate to the last grade of primary education; B4: GE + DALY + initial years of schooling + initial level of Gini index. 
(a) Countries above/below sample median of GDP per capita 1960; (b) SSA countries refers to Sub-Saharan Africa 


\section{Retrouvez la liste des « Documents de travail de l'IREDU » publiés ces trois dernières années :}

Documents de travail 2015 :

DT 2015-1 : "Access to Higher Education: the French case", Marie Duru-Bellat, janvier 2015

DT 2015-2 : "Les compétences sociales : quels apports dans la compréhension des différences de réussite à l'école primaire ?", Sophie Morlaix, janvier 2015

DT 2015-3 : "Effets du lieu de résidence en ZUS sur les parcours et le sentiment de discrimination des jeunes issus de l'immigration", Yaël Brinbaum et Christine Guégnard, mai 2015

DT 2015-4 : "Une éducation pour tous de qualité : une analyse statistique sur les pays d'Afrique subsaharienne", Nadir Altinok, juin 2015

DT 2015-5 : "The Unfolding of Gender Gap in Education", Nadir Altinok and Abdurrahman Aydemir, juin 2015

\section{Documents de travail 2014 :}

DT 2014-1 : "L'équité : un fil rouge des politiques éducatives nationales", Alain Mingat et Francis Ndem, avril 2014

DT 2014-2 : "Equity: a cornerstone in designing national education policies", Alain Mingat et Francis Ndem, avril 2014

\section{Documents de travail 2013 :}

DT 2013-1 : "Les étudiants anticipent-ils correctement la valeur de leur diplôme sur le marché du travail ?", Claire Bonnard, Jean-François Giret, Marielle Lambert-Le Mener, avril 2013

DT 2013-2 : "Territoire et formation : quelle dynamique de rapprochement ? Réflexions sur une expérience en cours", André Giffard, avril 2013

DT 2013-3 : "Le niveau de compétences de base peut-il expliquer le déclassement ou le surclassement sur le marché du travail ?", Aline Branche-Seigeot, Jean-François Giret, mai 2013

DT 2013-4 : "Les choix des étudiants et l'efficacité des actions de soutien : évaluation de dispositifs du programme de réussite en licence", Cathy Perret et Julien Berthaud, juin 2013

DT 2013-5 : "A New International Database on Education Quality: 1965-2010", Nadir Altinok, Claude Diebolt, Jean-Luc Demeulemeester, Novembre 2013

Les Documents de travail de l'IREDU n'engagent que leurs auteurs. L'objet de leur diffusion est de stimuler le débat et d'appeler commentaires et critiques. Ils peuvent ensuite donner lieu à des publications dans des revues scientifiques.

Working Papers do not reflect the position of IREDU but only their author's views. 